\title{
Construction and Implementation of Calligraphy Course in Normal Universities From the Perspective of Aesthetic Education-Taking Leshan Normal University for Example
}

\author{
Shengjing $\mathrm{Wu}^{1, *}$, Ju Wang ${ }^{2}$ and Xiaoyun $\mathrm{Wan}^{1}$ \\ ${ }^{1}$ College of Fine Arts, Leshan Normal University, Leshan, China \\ ${ }^{2}$ College of Teacher Education, Leshan Normal University, Leshan, China \\ *Corresponding author. Email:826934920@qq.com
}

\begin{abstract}
As an elective course of normal university, calligraphy course not only trains the writing skills of normal students, but also shows out the function of optimizing the knowledge structure and improving the comprehensive attainment. This article, which takes the case of the Leshan Normal University, will focus on analyzing the cognitive level and practical significance in the teaching process and clarifying the relationship between the calligraphy course and the aesthetic education for college students. Therefore, as a public elective course, we can determine the goal and ideas of teaching reform in calligraphy. This paper will attempt to start from the actual teaching of the calligraphy course, discuss the reform background of the public elective course of calligraphy in colleges and universities, and probe into the practice of teaching reform in calligraphy course in normal universities, from the arrangement of the background of the course, the measures to promote the calligraphy aesthetic education, and the results obtained, etc.

Keywords: calligraphy; aesthetic education; public courses; measures
\end{abstract}

\section{INTRODUCTION}

In August 2011, the Ministry of Education issued the opinions on calligraphy education in primary and secondary schools, which clearly stated the importance of calligraphy education and pointed out that calligraphy education should start at the basic education stage, while the lack of teachers in basic education is a key issue. It makes the popularization of calligraphy and the training of talents in normal colleges and universities becoming valued. In September 2015, the State Council General Office issued the opinions on comprehensively strengthening and improving aesthetic education in schools, which pointed out the importance of strengthening aesthetic education in schools, and proposed that the normal development and teaching of aesthetic education curriculum should be ensured. Also in January 2017, the State Council General Office published the opinions on the implementation of the project for the transmission and development of China's outstanding traditional culture, which stressed the importance of the transmission of Chinese traditional culture in the current era, and required relevant departments to strengthen the promotion and popularization of traditional culture and art, such as calligraphy. The publication of these above-mentioned documents not only shows that the traditional culture is greatly valued by our country, but also shows the importance of strengthening the artistic inheritance and aesthetic education of calligraphy in all-level schools.

\section{PRESENT SITUATION}

Calligraphy is not equal to writing, the normal writing of Chinese characters, while normal writing only meets the lowest aesthetic standard of Chinese calligraphy. However, influenced by the cultural environment nowadays, the contemporary college students' aesthetic cognition of calligraphy is vague, unclear and even wrong.

At present, few people have received the real calligraphy aesthetic education, which means in the general public's aesthetic cognition, the calligraphy aesthetic only contains the normative writing, reflected in writing steadily and affluently, neatly and symmetrically, with the beautiful appearance. But even this kind of low level of aesthetics is not attachable by most contemporary students, due to the heavy dependence on e-writing in their lives, and the traditional writing way is gradually replaced by the keyboard, since now the university teaching are promoting electronic homework and network examination and so on. Chinese calligraphy has great significance in philosophy and culture, and it has the characteristics of interdisciplinary with literature, history, philosophy and aesthetics. At the same time, calligraphy is a traditional art, existing as an independent art form, which focuses on the pursuit of artistic style and aesthetic conception of the 
works, and lies in expressing the writer's mind and emotion. Therefore, calligraphy education should be combined with Chinese traditional history and culture, and observed from the aesthetic view of art appreciation. For the aesthetic works of art, only in accordance with its own artistic characteristics, can the transmission and innovation of calligraphy art be embodied. From this point of view, the calligraphy class teaching in normal universities should pay more attention to the art aesthetic education in calligraphy. Through the study of the calligraphy class, students can not only go deep into the vast treasure house of art in the history of Chinese calligraphy, but also feel the excellent traditional national culture, and learn to distinguish the elegance and vulgarity for beauty of calligraphy, then truly gain a meaningful artistic experience. All these mentioned above should be the subject which need to be seriously considered and practiced by college calligraphy teachers.

In normal universities, the main way for students to receive aesthetic education is to take part in the study of public elective art courses. Through the teaching activities of the courses, students are guided to have aesthetic experience, which can imperceptibly influence students' aesthetic level. Therefore, it is necessary to effectively strengthen the construction of the public calligraphy course in normal universities, vigorously promote the reform and innovation of the calligraphy art course, and truly improve the writing ability and the artistic aesthetic ability of contemporary college students, in order to achieve excellent heritage of Chinese traditional culture.

\section{THE IMPLEMENT WAY}

The "Aesthetic" experience is a process actually, including the cooperation of multi-thinking process among the concrete thinking, abstractive thinking and spatial thinking. The learning goal of calligraphy course is not to make sure how much technical content the students have learned, but to comprehensively enhance the learners' calligraphy appreciation level and artistic aesthetic ability, and then improve their comprehensive cultural quality, in the process of calligraphy learning. Therefore, multiple measures should be taken to realize the function of calligraphy aesthetic education in the teaching of common calligraphy course in normal universities. Now, take the Leshan Normal University's recent performance as an example.

\subsection{The Promotion of the Curriculum Status and the Aesthetic Cognition for Teachers and Students}

For normal universities, the status of calligraphy course can be divided into two kinds: professional elective course and general elective course. From the perspective of subject setting, no matter what kind the elective form is, its course status is one of elective courses. Then there will be certain differences in the subject setting, teaching time, the goal task with the compulsory course, which can also affect the subject cognition naturally. Therefore, how to determine that the status of the curriculum is the basis to improve the implementation of art aesthetic education for normal universities, is a pivotal problem of promoting the calligraphy aesthetic education.

For many years, the Leshan Normal University has attached great importance to the public art class, and has put forward high requirements for the positioning of the calligraphy class, thus adopted multi-channel methods and measures. In the curriculum setting, firstly, the school teaching department requires that the calligraphy course should be long-term fixed as a professional elective course in some normal majors, while students must choose one of them during the undergraduate period. Secondly, the Academic Affairs Office provides an opportunity once a year in the first and second semesters respectively, for teachers and all normal students to apply for public art classes, while strongly encouraging arts teachers to apply for public art classes. Thirdly, the school sets up 1 or 2 weeks for teaching practice week courses every semester. During this period, apart from professional related practice class courses, most teacher-training majors will set up art class practical participation courses, which also includes the study and practice of calligraphy skills.

The improvement of the understanding of calligraphy aesthetic teaching must be under the participation of both teachers and students, in order to realize the aim of aesthetic education in course teaching. As a group of teachers in the campus culture, the depth of their knowledge of calligraphy will undoubtedly have a direct or indirect impact on students' cognition of calligraphy. Eventually, these will merge into the education of calligraphy teachers, and mutually affect the implementation of calligraphy aesthetic education for students. As teachers with calligraphy attainments who are engaged in teaching other subjects, they can also be integrated with calligraphy teachers, and be carried out in the form of team-building. At the same time, the application of scientific research can be supported by corresponding funds, which can fully play the role of this group of teachers in the dissemination of calligraphy art and culture on campus. Chinese calligraphy has a complex and numerous techniques, and a variety of styles, making the professional skills of calligraphy shows out the complex and changeable technical requirements.

As a public course, it is not enough to only rely on the teachers who are engaged in calligraphy education to realize the function of aesthetic education of calligraphy course, which means the atmosphere of culture on campus is needed, too. In terms of disciplines, there are interdisciplinary features among literature, history, 
philosophy, aesthetics and calligraphy. That's why the cognition and study of calligraphy will be more difficult than other majors. Therefore, it can change the function of calligraphy aesthetic education and teaching effect to raise the subject status and cognitive height of calligraphy from the subject status and learning psychology cognition.

Based on those mentioned above, the Leshan Normal University has also taken a number of measures to monitor and optimize the teaching effect of the course, which is also the basis for the reform of calligraphy classroom teaching in schools.

\subsection{Optimizing Curriculum Structure and Extending Classroom Teaching}

As the main course of aesthetic education, the public course of calligraphy is not only about the study of calligraphy in teaching practice, but also makes the professional skills of calligraphy present the complicated and changeable skill requirement, since the Chinese calligraphy has many complicated techniques and various styles. In terms of disciplines, there are interdisciplinary features among literature, history, philosophy, aesthetics and calligraphy. Therefore, in the teaching reform of the calligraphy course, on the premise of paying attention to the training of students' calligraphy skills, the aesthetic cognition of classical calligraphy works is added to the classroom teaching. So it has not only the training of writing level, but also the imperceptible infiltration of aesthetic cognition, so as to enhance the students' aesthetic cognition of calligraphy.

Calligraphy teaching in elective courses is mostly done in comprehensive classrooms with narrow desks, limited space and environment lacking calligraphy atmosphere, no matter the student's writing ability training or the calligraphy esthetic promotion, will receive certain influence.

In order to better promote the start of calligraphy courses, the calligraphy practice laboratory was established by School of Literature and Mass Media in 2014. With the aim of helping college students to have more ways and opportunities for hands-on experience in calligraphy, it can enhance their hands-on skills and promote the improvement of their thinking ability of aesthetic education. The establishment of calligraphy training laboratory not only meets the needs of calligraphy lovers' writing training and aesthetic appreciation, but also encourages non-calligraphy lovers to become calligraphy experts and continue to train them.

In order to better realize students' calligraphy experience, the reform of calligraphy classroom teaching also relies on the forms of college students' association, College Students' innovative and pioneering practice, subject contest, college students' Art Festival, etc. It realizes the organized connection inside and outside the class, strengthens the way of improving the function of calligraphy aesthetic education, and makes calligraphy course and calligraphy practice become a part of school aesthetic education.

\subsection{The Establishment and Evaluation of Multi-channel Cultivation Form}

In order to achieve better calligraphy education, on the basis of the original classroom teaching, relying on the super-star, MOOC and other platforms to build calligraphy network courses, which will share the classroom teaching content and related knowledge links. On the above platform, students' learning can be played repeatedly, which can deepen their learning and imitation of calligraphy techniques. At the same time, students can express their opinions in time to realize a low-cost and high-efficiency learning mode, realizing the classroom inside and outside the orderly extension by corresponding with classroom teaching. Also relying on self-media to achieve the platform for learning and communication is a convenient and effective way. For example, communication can be conducted on mobile applications such as Wechat and QQ, and flexible online courses can also be taught by teachers. While saving public teaching resources, students can meet their own learning requirements, and learn selectively and flexibly according to their own practice and location.

As an art form, calligraphy should be changeable in the evaluation system. The evaluation of learning in public calligraphy courses encourages humanistic evaluation criteria. It is suggested that flexible and open examination methods should be adopted and process evaluation should be emphasized. Instead of focusing on the feedback of calligraphy writing, it is a comprehensive assessment from writing and perception to experience, which can stimulate students' awareness of active participation, and change students' learning ways from passive acceptance to active seeking. While solving the credit requirement of students, it can realize the process that calligraphy teachers inspire and guide students by copying and creating calligraphy, and help students to experience the beauty of calligraphy. So in this process, the function of aesthetic education will be realized.

\section{RESULTS}

After paying attention to the study of aesthetic education in the public course of calligraphy, both the teaching and the training mode of calligraphy have been continuously optimized, and many remarkable 
achievements have been made, which are mainly reflected in the following aspects.

\subsection{The Improvement of Writing Skill and Aesthetic Level}

The aim of setting up calligraphy courses in normal universities is not only to improve students' writing cognition and writing level on the basis of their skills, but also to feel the beauty of calligraphy art in the process of learning, and master the aesthetic judgmental standards of calligraphy works, so as to achieve the goal of aesthetic education. On this basis, students can master a certain means of technical expression of calligraphy, and lay a foundation for the inheritance of traditional culture and art.

Through the efforts from the level of cognition and the opening of practical training laboratory for the public elective course of calligraphy in Leshan Normal University, students gradually realize that the learning of calligraphy is not only the writing training, but also the professional and systematic skill training during the learning, which is the main way to improve their aesthetic cognition level. Now, for a number of students at the Leshan Normal University, it have seen a marked change that standardizing the writing of Chinese characters is not the aim of study, and their perception of calligraphy course is no longer chosen solely for the sake of academic credit, but to constantly improve their aesthetic perception and acquaint the artistic charm and cultural details of Chinese calligraphy. This really embodies the function of carrying forward the broad and profound traditional culture of China.

\subsection{The Participation of Subject Competitions}

The subject contest is not the training goal of non-calligraphy majors, but the participation of the subject contest is an effective way to test the results of learning, which can improve the students' sense of participation of the contest. At the same time, through the communication and learning in the competition, their creative vision is constantly broaden, and their aesthetic vision is gradually improved.

In recent years, since the university have paid enough attention to the aesthetic consciousness of the subject, and have been good at discovering the special skills of students in non-calligraphy majors during the classroom teaching of public calligraphy courses, and have been conscious of strengthening the training, the Leshan Normal University has achieved many outstanding results in national, provincial, municipal and school level calligraphy competitions.
Table 1. Awards statistics of calligraphy competition

\begin{tabular}{|c|c|c|c|}
\hline $\begin{array}{c}\text { National level } \\
\text { (Chinese } \\
\text { Calligrapher's } \\
\text { Association) }\end{array}$ & $\begin{array}{c}\text { Provincial level } \\
\text { (Sichuan } \\
\text { Calligrapher's } \\
\text { Association) }\end{array}$ & $\begin{array}{c}\text { Provincial } \\
\text { department } \\
\text { of education }\end{array}$ & $\begin{array}{c}\text { Municipal } \\
\text { level and } \\
\text { School } \\
\text { level }\end{array}$ \\
\hline 2 times & 32 times & 57 times & 110 times \\
\hline
\end{tabular}

\subsection{Highlighting Characteristics and Creating Excellent Courses}

In the course of the reform of the public course of calligraphy, there will inevitably be many problems. Sorting out and rethinking those problems, promoting the reform of the teaching constantly, grasping the characteristics of the subject, and declaring the construction of high-level public elective courses, make it become a part of the campus cultural characteristics. In August 2017, the textbook calligraphy training course, which is more suitable for the classroom teaching of calligraphy education in normal universities, was published by Tsinghua University. In 2019, the study of curriculum construction and skill training model for normal school students was successfully established as a top-class applied demonstration course in Leshan Normal University.

\section{ISSUES THAT NEED TO BE SOLVED}

\subsection{The Insufficiency of Teachers}

The shortage of calligraphy teachers is a common problem in many colleges and universities. As far as the Leshan Normal University is concerned, there are currently nearly 17,000 students in the school, so the average students in each grade need to carry out basic calligraphy education and calligraphy aesthetic education is more than 4000. There are now five calligraphy teachers graduating from the Leshan Normal University, and four of them are not majoring in calligraphy but able to teach calligraphy as well. If we really take care of all the students, given the current strength of the teaching force, it's almost impossible. Of course, in accordance with the current school curriculum and teacher allocation plan, the introduction of a large number of calligraphy teachers is also unrealistic. Therefore, the difficulties in the teaching staff, but also need to develop ideas in the future, such as hiring some calligraphers in the community to do part-time teachers is necessary, so as to try to find a proper solution.

\subsection{The Cultivation of Students' Interests}

The improvement of calligraphy aesthetics in course teaching can only be realized by the participation of 
both teachers and students, especially for the target audience. "to cultivate students to inherit the excellent traditional Chinese culture has become the inherent requirement and essence of the construction of colleges and universities."[1] Therefore, to enhance students' aesthetic awareness in the process of learning calligraphy takes the most priority. However, both the training of calligraphy skills and the aesthetic education require students' meditation in order to go deep into it, while modern students are keener on new-style culture and technical means, most students are not willing to spend a lot of time and energy to accept the aesthetic education of calligraphy. Although the Leshan Normal University has effectively solved some problems by taking elective courses and offering courses, it would be more effective if the majority of students accepted the course from an interest point of view, which also need in-depth study in future.

\subsection{Opening a Wider Way of Training Artistic Talents}

As a school which attaches great importance to the education of traditional culture and the popularization of aesthetic education, the Leshan Normal University has made a multi-channel and multi-form attempt at teaching reform and methods in the popularization of calligraphy and aesthetic education, also played a certain good teaching effect. However, as far as the current situation is concerned, the work done is not enough, and the educational and teaching approaches developed can't meet the current needs of aesthetic education. So we hope to find more effective and diversified ways of training artistic talents in the future exchanges and cooperation with similar colleges and universities.

\section{CONCLUSION}

The opening of the public course of calligraphy in Leshan Normal University has made a lot of flexible and diverse working methods in the popularization of calligraphy aesthetic education and the cultivation of calligraphy specialty students, while also achieved remarkable and valuable results. However, if we want to improve the calligraphic aesthetic ability of normal school students in an all-round way and maximize the transmission and embodiment of traditional culture in calligraphy, we still need to combine the artistic features of calligraphy with the actual combination of education in the first place, and pay more attention to the aesthetic function of calligraphy, in the efforts done in the current education under the actual guidance. In the calligraphy teaching, the hardware facilities of calligraphy curriculum, the strength disposition of calligraphy teachers and others are all the questions which need to consider urgently. In order to promote the improvement of calligraphy teaching, we try to integrate calligraphy with other related subjects to form a multi-disciplinary course system, and excavate the great depth of calligraphy teaching, then carry on the depth mining to the calligraphy teaching content. At the same time, we should also try to build online calligraphy teaching courses on the platform by relying on modern educational technological ways, stimulate students' interest in calligraphy learning from various angles, and improve calligraphy artistic attainments of teachers and students, to achieve the aim of art popularization and calligraphy aesthetic education of calligraphy courses in normal universities.

\section{ACKNOWLEDGMENT}

This paper is the research result of the project of "the first-class undergraduate construction and research project of Leshan Normal University in 2019": The course construction of calligraphy and the training mode of normal students' skills (Project No. KG2019-1-15).

\section{REFERENCES}

[1] Li Chen, "The present situation of calligraphy education in colleges and universities and the analysis of its reform ideas," [J]. National Exhibition of China, 2020.10. (In Chinese)

[2] Zhenlian Chen, "Pedagogy of calligraphy," [M]. Calligraphy and Painting Publishing House, 2018.3. (In Chinese)

[3] Hongxu Li, "The present situation analysis and countermeasure research of normal university education," [J]. Science and education guide, 2019.6. (In Chinese)

[4] Bin Tang, "A study on the innovation of the teaching mode of calligraphy aesthetic education in the second classroom of colleges and universities," [J].

Appreciation and criticism of calligraphy, 2021.2. (In Chinese)

[5] Zhizhong Wang, "On the dialectical view of the aesthetic education of college calligraphy," [J]. Art and design, 2021.1. (In Chinese)

[6] Jingbo Zou, "The effect of calligraphy teaching on college students aesthetic education," [J]. Cultural and educational materials, 2020.2. (In Chinese) 